Tech. Rep. INT-GTR-309. U.S. Department of Agriculture, Forest Service, Rocky Mountain Research Station, Ogden, UT. p 43.

Toyoda, K., N. C. Collins, A. TAKahashi and K. SHIRAsU (2002): Resistance and susceptibility of plants to fungal pathogens. Transgenic Res. 11: 567-582.

WeIR, B. S. and C. C. Cockerham (1984): Estimating Fstatistics for the analysis of population structure. Evolution 38: 1358-1370.

WeIsBerG, S. (1985): Applied Linear Regression. John Wiley \& Sons, New York. 324 pp.
Williams, C. G. and O. SAVOLAINEN (1996): Inbreeding depression in conifers: Implications for breeding strategy. Forest Sci. 42: 102-117.

WRIGHT, S. (1951): Evolution and the genetics of populations. Vol. II. University of Chicago Press, Chicago, IL.

YANDELL, U. G. (1992): An allozyme analysis of whitebark pine (Pinus albicaulis Engl.). Masters Thesis University of Nevada, Reno.

ZEGLEN, S. (2002): Whitebark pine and white pine blister rust in British Columbia, Canada. Can. J. For. Res. 32: 1265-1274.

\title{
Genetic diversity of Anadenanthera colubrina Vell. (Brenan) var cebil, a tree species from the South American subtropical forest as revealed by cpSSR markers
}

\author{
By M. E. Barrandegur ${ }^{\left.1), 3),{ }^{*}\right)}$, M. V. García ${ }^{1), 3), 4), *}$, C. F. ArgüEllesi ${ }^{1)}$ and G. D. L. Cervigni ${ }^{2), 3)}$
}

(Received 14 ${ }^{\text {th }}$ April 2010)

\begin{abstract}
Anadenanthera colubrina var cebil is a tree species native to the Upper Parana Atlantic Forest where human activities have severely impacted causing deep fragmentation. Microsatellites are not available in this species. Therefore, the first objective of this study was to generate chloroplast simple sequence repeats (cpSSR) by cross-species transfer. Understanding the evolutionary dynamics of subdivided populations is an important matter. In this way, a first approach to the characterization of the haplotypic diversity within and between populations as well as the genetic structure of native Argentinean populations were the main goals of this study.

Twenty four individuals from two populations of the Misiones province were studied and four cpSSR loci were tested. Two of them exhibited polymorphic patterns leading to the identification of $11 \mathrm{cpDNA}$ haplotypes with high mean genetic diversity $(G D=0.73)$. The minimum spanning network defined three clear groups which can be assigned to at least three subpopulations. AMOVA indicated that the total variance showed the highest percentage of variation $(48 \%)$ within subpopulations with a fixation index $\left(\mathrm{F}_{\mathrm{ST}}\right)$ statistically significant $\left(\mathrm{F}_{\mathrm{ST}}=0.520 ; \mathrm{p}<0.05\right)$. Brown's two loci component analy-

1) Departamento de Genética. Facultad de Ciencias Exactas, Químicas y Naturales. Universidad Nacional de Misiones.

2) Centro de Estudios Fotosintéticos y Bioquímicos.

3) Consejo Nacional de Investigaciones Científicas y Técnicas (CONICET).

$\left.{ }^{4}\right)$ Corresponding author: MARIA Victoria García. Genética de Poblaciones y Cuantitativa, Departamento de Genética, Facultad de Ciencias Exactas, Químicas y Naturales, Universidad Nacional de Misiones, Félix de Azara 1552, (3300) Posadas. Misiones, Argentina. E-Mail: vgarcia@fceqyn.unam.edu.ar.

*) These authors contributed equally to this work.
\end{abstract}

sis indicated that substructure population is present. Jost's differentiation global index $\left(\mathrm{D}_{\text {est }}\right)$ was 0.049 while $\mathrm{D}_{\text {est }}$ pairwise comparison reflected a certain level of genetic structure.

The high diversity level detected in the adult trees of A. colubrina var cebil from the populations under study could be due to recent human influence. In this way, the reduction in population size caused a reduction in the number of trees leading to surviving trees showing the historical diversity of the populations analyzed.

Key words: Upper Parana Atlantic Forest, Curupay, intraspecific genetic diversity, cpSSR cross-species transfer.

\section{Introduction}

The study of the genetic diversity distribution, population structure and evolutionary features of a species native range is of particular relevance when evaluating their long-term variability and fitness (GómEz et al., 2002).

Anadenanthera colubrina Vell. Brenan var cebil, (Fabaceae, Mimosoideae) known locally as curupay, is a tree species native to the South American subtropical forest. Curupay trees can be found in the Upper Parana Atlantic Forest, which extends from Brazil into the northern part of Argentina, where human activities have had a severe impact leading to deep fragmentation. These trees can reach up to $35 \mathrm{~m}$ in height, with flowers arranged in hermaphrodite inflorescences and long legume fruits with narrow and flattened seeds (JUSTINIANO and FREDERICKSEN, 1998; Cialdella, 2000). Their floral traits show that pollination is performed by bees and seed dissemination occurs over short distances by anemochory - autochory after pod dehiscence (JUSTI- 
NIANO and FredericKSEN, 1998; ABRAHAM DE NoIR et al. 2002). Curupay has high potential for sustainable forest management, and could play a key role in the recovery of degraded forest areas (JUSTINIANO and FREDERICKSEN, 1998).

Further exploration of the evolutionary dynamics of subdivided populations is of key importance since the remaining natural areas continue to become increasingly smaller and fragmented (LAROCHE and DURAND, 2004). Disturbed habitats could threaten many plant and animal populations through possible erosion of their genetic variability by different mechanisms such as bottlenecks, genetic drift and inbreeding (LAROCHE and DURAND, 2004).

The organization of the circular chloroplast DNA (cpDNA) genome of land plants is extremely conserved, with genes usually occurring in the same order (GRIVET et al., 2001). Chloroplast DNA variation is predominantly maternally inherited in most Angiosperms (HARRIS and INGRAM, 1991) and this seems to be the case in A. colubrina var cebil. The non-recombinant, uniparental inheritance and haploid nature of this organelle genome makes it a useful tool for evolutionary studies (Provan et al., 2001) as well as for the examination of historical colonization processes based on cpDNA variation (CAVERS et al., 2004). cpDNA acts as a single inheritable unit (DoulATY BANEH et al., 2007), and the assignment of a cpSSR "haplotype" to any given accession is a very straightforward process due to the high copy number of cpDNA molecules per cell along with the lack of recombination in the chloroplast genome (BRYAN et al., 1999a). Non-coding intron and intergenic spacers are particularly variable and contain microsatellite and other kinds of polymorphisms even between closely related individuals and taxa in a range of plants groups (CESARE et al., 2010).

Characterization of new microsatellites is costly and technically demanding considering they must be isolated de novo from species being examined for the first time (PeAKall et al., 1998; KaUndun and Matsumoto, 2002; ZANE et al., 2002). Fortunately, DNA regions flanking microsatellite loci are relatively conserved and primers designed in a source species have been used successfully to amplify SSRs in closely related taxa (KAUNDUN and MATSUMOTO, 2002). In the case of chloroplast microsatellites (cpSSRs), repetitive flanking regions are even more conserved across genera, allowing for the design of universal chloroplast primers potentially useful for a wide range of species (CATO and RICHARDsON, 1996). Chloroplast microsatellites inherit several important and unique characteristics from the organelle genome in which they occur (EBERT and PEAKALL, 2009).

Maternally inherited markers are the most suitable for phylogeographic reconstructions since they allow the study of seed movement. However, paternally inherited plastid DNA polymorphism could provide insights into past genetic processes (MARCHELLI et al., 2010). The pattern of genetic differentiation varies whether it considers maternal or paternal plastid inheritance. In the first case, it has been reported low intraspecific genetic variation (MARChelli and Gallo, 2006; PAstorino et al.,
2009). On the other hand, MARCHELLI et al., (2010) have reported very low genetic differentiation in Araucaria araucana, as expected for a paternally inherited plastid that moves with pollen grains.

Despite the value of chloroplast markers in population genetics and the growing number of studies developing and applying cpSSRs, their use is still largely centered on economically important plants and their relatives. The potential of cpSSRs to offer unique insights into ecological and evolutionary processes in wild plant species remains to be fully realized (EBERT and PEAKALL, 2009).

Considering that microsatellites have not been described for $A$. colubrina, the first objective of this study was to generate cpDNA markers for this novel species by cross-species transfer from Nicotiana tabacum. These markers would be subsequently used to further explore the haplotypic diversity within and among populations as well as the genetic structure present in native Argentinean populations of A. Colubrina.

\section{Materials and Methods}

\section{Plant material}

Two populations of $A$. colubrina located in Santa Ana (27 $25^{\circ} 55.92^{\prime \prime S} 55^{\circ} 34^{\prime} 16.68^{\prime \prime} \mathrm{W}$, altitude $153 \mathrm{~m}$ asl) and Candelaria $\left(27^{\circ} 26^{\prime} 58.2^{\prime \prime} \mathrm{S} 55^{\circ} 44^{\prime} 20.22^{\prime \prime} \mathrm{W}\right.$, altitude 104 $\mathrm{m}$ asl), in the province of Misiones (Argentina), were sampled (Figure 1). The distance between populations was nearly $17 \mathrm{~km}$ and two subpopulations approximately $3 \mathrm{~km}$ apart were considered within each population. Trees over $0.20 \mathrm{~m}$ in normal diameter were considered as adult trees. Between four and seven adult trees were sampled for each subpopulation. In some cases trees were only $3 \mathrm{~m}$ apart due to their absence in some areas. The low number of sampled trees is a consequence of the high levels of deforestation in the region. Leaves collected were conserved with silica gel in labeled plastic bags.

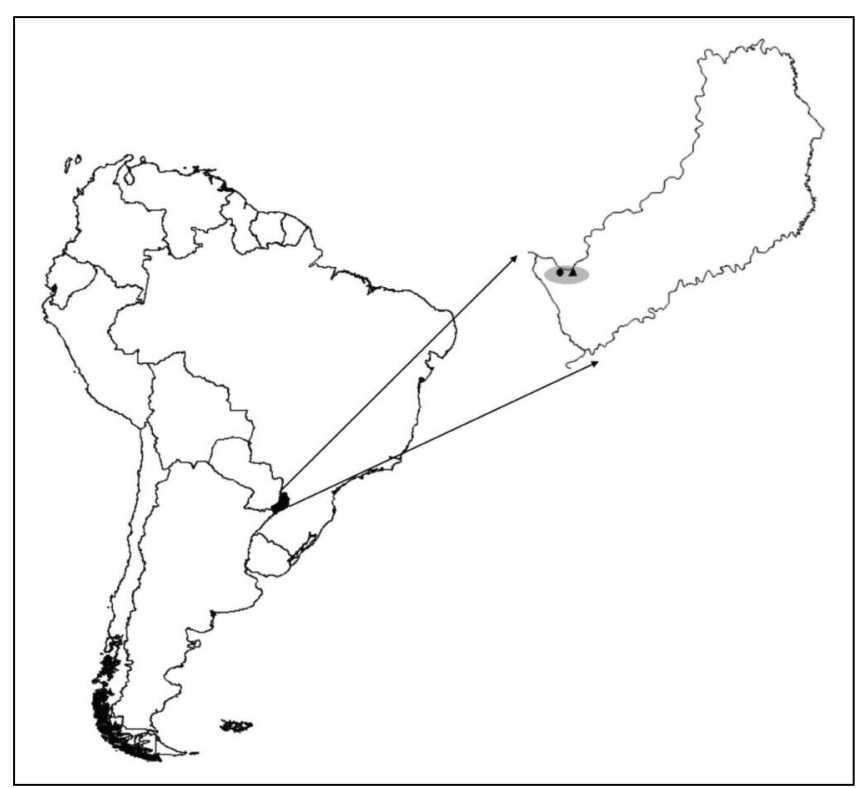

Figure 1. - Location of A. colubrina var cebil populations under study. : Santa Ana, $\mathbf{\Delta}$ : Candelaria. 
Table 1. - Characteristics of four novel microsatellite loci isolated from A. colubrina var cebil.

\begin{tabular}{|c|c|c|c|c|c|c|}
\hline Locus & $\begin{array}{l}\text { Primer sequences } \\
\qquad\left(5^{\prime}-3^{\prime}\right)\end{array}$ & $\mathrm{T}_{\mathrm{a}}\left({ }^{\circ} \mathrm{C}\right)$ & $\begin{array}{l}\text { Allele size range } \\
\qquad(\mathrm{bp})\end{array}$ & $\begin{array}{c}\mathrm{N}^{\circ} \\
\text { alleles }\end{array}$ & Repeat motif & $\begin{array}{c}\text { Genebank } \\
\text { Accession number }\end{array}$ \\
\hline AcCcmp3 & $\begin{array}{l}\text { CAGACCAAAAGCTGACATAG } \\
\text { GIT"ICATTCGGCICCI"IAT }\end{array}$ & 45 & 50 & 1 & $(\mathrm{~T})_{8}$ & FJ560722 \\
\hline AcCcmp5 & $\begin{array}{l}\text { TGTTCCAATATCTTCTTGTCATTT } \\
\text { AGGTTCCATCGGAACAATTAT }\end{array}$ & 47 & 130 & 1 & $(\mathrm{~T})_{7} \mathrm{C}(\mathrm{A})_{3} \mathrm{~T}(\mathrm{~A})_{10} /(\mathrm{A})_{10}$ & FJ560723 \\
\hline$A c N t c p 8$ & $\begin{array}{c}\text { ATATTGTTTTAGCTCGGTGG } \\
\text { TCATTCGGCTCCTTTATG }\end{array}$ & 52 & $352-363$ & 6 & $(\mathrm{~T})_{10}$ & FJ560724 \\
\hline AcNtcp 9 & $\begin{array}{c}\text { CTTCCAAGCTAACGATGC } \\
\text { CTGTCCTATCCATTAGACAATG }\end{array}$ & 50 & $439-459$ & 5 & $(\mathrm{~T})_{6} /(\mathrm{A})_{7} /(\mathrm{A})_{8}$ & FJ560725 \\
\hline
\end{tabular}

Table 2. - Allelic frequencies in the studied subpopulations of A. colubrina var cebil.

\begin{tabular}{|c|c|c|c|c|c|c|}
\hline Locus & Allele & Candelaria A & Candelaria B & Santa Ana A & Santa Ana B & Total \\
\hline & $\mathbf{3 5 2}$ & 0,000 & 0,000 & 0,143 & 0,000 & 0,042 \\
\cline { 2 - 7 } & $\mathbf{3 5 4}$ & 0,000 & 0,000 & 0,143 & 0,000 & 0,042 \\
\cline { 2 - 7 } AcNtcp8 & $\mathbf{3 5 8}$ & $\mathbf{0 , 3 3 3}$ & 0,000 & 0,143 & 0,000 & 0,125 \\
\cline { 2 - 7 } & $\mathbf{3 6 1}$ & $\mathbf{0 , 5 0 0}$ & $\mathbf{0 , 5 7 1}$ & 0,000 & $\mathbf{1 , 0 0 0}$ & $\mathbf{0 , 5 0 0}$ \\
\cline { 2 - 7 } & $\mathbf{3 6 3}$ & $\mathbf{0 , 1 6 7}$ & 0,429 & 0,000 & 0,000 & 0,167 \\
\cline { 2 - 7 } & $\mathbf{N A}$ & 0,000 & 0,000 & 0,571 & 0,000 & 0,167 \\
\hline \multirow{4}{*}{ AcNtcp9 } & $\mathbf{4 3 9}$ & 0,000 & 0,000 & 0,714 & 0,000 & 0,208 \\
\cline { 2 - 7 } & $\mathbf{4 4 5}$ & $\mathbf{0 , 1 6 7}$ & 0,000 & 0,000 & 0,000 & 0,042 \\
\cline { 2 - 7 } & $\mathbf{4 4 9}$ & 0,333 & 0,000 & 0,286 & 0,500 & 0,292 \\
\cline { 2 - 7 } & $\mathbf{4 5 2}$ & $\mathbf{0 , 5 0 0}$ & $\mathbf{0 , 5 7 1}$ & 0,000 & $\mathbf{0 , 5 0 0}$ & $\mathbf{0 , 3 7 5}$ \\
\cline { 2 - 7 } & $\mathbf{4 5 5}$ & $\mathbf{0 , 0 0 0}$ & 0,429 & 0,000 & 0,000 & 0,125 \\
\hline
\end{tabular}

\section{DNA extraction}

Dry young leaves (about $5 \mathrm{~g}$ ) were ground to a fine powder with liquid nitrogen using a ceramic pestle. Next, genomic DNA was isolated using the Rapid One Step Extraction (ROSE) method described by STEINER et al. (1995), modified as follows: $1 \%$ of polyvinylpolypyrollidone (PVPP) was added to the extraction buffer and organic washes were performed (GARCÍA et al., 2007). DNA was precipitated by addition of cold isopropanol and $3 \mathrm{M} \mathrm{NaCl}$.

DNA concentration was estimated electrophoretically against a known amount of $\lambda$ DNA marker used as standard.

\section{Primer selection}

Four chloroplast loci were assayed using the universal primers pairs Ccmp3 and Ccmp5 developed by WEISING and GARDNER (1999) and primers pairs Ntcp8 and Ntcp9 developed by BRYAN et al. (1999b). These primers were intended to amplify four different loci according to the conserved nature of intergenic or intronic regions in higher plant chloroplasts (CHENG et al., 2003). Oligonucleotide sequences described in Table 1 were synthesized by the Operon Tech Corporation.
Polymerase chain reaction (PCR) assay

Amplification reactions were carried out in a final volume of $30 \mu \mathrm{l}$ containing $0.2 \mathrm{mM}$ dNTPs, $2.5 \mathrm{mM} \mathrm{MgCl}_{2}$, $2 \mu \mathrm{M}$ of primer, $1 \mathrm{x}$ reaction buffer $(750 \mathrm{mM}$ Tris-HCL $\mathrm{pH} 8.8,200 \mathrm{mM}\left(\mathrm{NH}_{4}\right)_{2} \mathrm{SO}_{4}, 0.1 \%$ Tween 20), 0.75 units of Taq polymerase (\#EP0402 Fermentas) and approximately $17 \mathrm{ng}$ of DNA template. Amplifications were performed using a Techne PHC - 3 Dri - Block ® Cycler as follows: (i) initial denaturation at $94^{\circ} \mathrm{C}$ for $4 \mathrm{~min}$; (ii) 30 cycles of denaturation at $94^{\circ} \mathrm{C}$ for $30 \mathrm{~s}$, annealing temperature $\left[\mathrm{T}_{\mathrm{a}}\right]$ for $1 \mathrm{~min}$ and extension at $72^{\circ} \mathrm{C}$ for $30 \mathrm{~s}$; and (iii) final extension at $72^{\circ} \mathrm{C}$ for $5 \mathrm{~min}$. The $\mathrm{T}_{\mathrm{a}}$ values for the different primers were: $52^{\circ} \mathrm{C}(\mathrm{Ntcp} 8), 50^{\circ} \mathrm{C}$ (Ntcp9), $47^{\circ} \mathrm{C}(\mathrm{Ccmp} 3)$ y $45^{\circ} \mathrm{C}(\mathrm{Ccmp} 5)$.

\section{Visualization of PCR products}

DNA amplification was evaluated by gel electrophoresis using agarose $(2 \%)$ and TRIS Borate EDTA (TBE) buffer $(1 \mathrm{x})$. Gels were run at $5 \mathrm{v} / \mathrm{cm}$, stained with Ethidium Bromide $(0.5 \mu \mathrm{g} / \mathrm{ml})$, and visualized under UV light (SAMBROOK et al., 1989).

Allele identification was carried out in $6 \%$ denaturing polyacrylamide gels $(43 \mathrm{~cm} \times 35 \mathrm{~cm} \times 0.4 \mathrm{~cm})$ electrophoresed in $0.5 \mathrm{X}$ TBE buffer at $75 \mathrm{~W}$ for about 
Table 3. - Haplotypes defined by sizes of alleles (in bp) and haplotypic total frequency.

\begin{tabular}{cccc}
\hline \multirow{2}{*}{ Haplotype } & \multicolumn{2}{c}{ cpSSR locus } & Total Frequency \\
& AcNtcp8 & AcNtcp9 & \\
\hline H1 & 358 & 449 & 0.0833 \\
H2 & 358 & 445 & 0.0417 \\
H3 & 361 & 449 & 0.1250 \\
H4 & 363 & 452 & 0.1250 \\
H5 & 361 & 452 & $\mathbf{0 . 2 5 0 0}$ \\
H6 & 361 & 455 & 0.0833 \\
H7 & 363 & 455 & 0.0417 \\
H8 & NA & 449 & 0.0417 \\
H9 & 354 & 439 & 0.0417 \\
H10 & NA & 439 & 0.1250 \\
H11 & 352 & 439 & 0.0417 \\
\hline
\end{tabular}

$\mathrm{NA}=$ null allele .

60 min. Polyacrylamide gels were silver stained and a $100 \mathrm{bp}$ Ladder (BIORAD) was used for allele discrimination. Allele sizes were determined using the GQmol software available at http://www.ufv.br/dbg/gqmol/gqmol. htm (SCHUSTER and CRUZ, 2004).

\section{Sequencing of PCR fragments}

Amplified products from two individuals out of thirty samples analyzed were sequenced using forward and reverse primers in a MegaBACE ${ }^{1000}$ sequencer. Products were previously purified using the GFX PCR DNA and Gel Band Purification Kit (General Electric Healthcare). Sequences were edited using the Chromas lite 2.01 software available at http://www.technelysium.com.au/ chromas_lite.htlm and aligned using the BioEdit sequence alignment editor software available at http:// www.etoology.net/index.php/software/genetics/100-bioedit-709.html (HALL, 1999).

\section{Data analysis}

Different haplotypes were obtained by combining alleles from different loci. The terms locus and allele will be used to refer to a cpSSR region or a variant in size at a given accession, respectively. Not all primers used yielded amplification products for all individuals analyzed. On account of this, a null allele was considered when no product was detected after the amplification reaction using DNA from different extractions. Null alleles were taken into account for haplotypic definition. Allelic fre- quency was obtained for each locus. Haplotypic frequencies were obtained for each subpopulation and for all individuals. The number of shared haplotypes was estimated by direct counting.

Gene diversity was estimated as

$$
G D=\left(1-\sum p i^{2}\right) /(n-1)
$$

where $n$ is the number of alleles and $p$ is the frequency of the $i$ th allele (NEI, 1987). Due to the non-recombinant nature of the chloroplast genome, cpDNA haplotypes were treated as alleles at a single locus. This assessment was developed using the POPGENE software package (version 1.32) available at http://www.ualberta.ca/ fyeh/ (YEH and BOYLE, 1997).

Multilocus association variances were partitioned into single-locus and two-locus components following Brown's analysis for multilocus associations among and within subpopulations (BROWN and FELDMAN, 1981). In this analysis, single-locus and two-locus components were measured by their contributions to the variance in the number of heterozygous loci in two randomly chosen gametes. Variance components in the number of heterozygous loci determined for single locus effect were: Mean gene diversity $(\mathrm{MH})$, Variance of diversity $(\mathrm{VH})$ and Wahlund's effect (WH). Variance components in the number of heterozygous loci determined for two-locus effect were: Mean linkage disequilibrium (MD), Wahlund's effect (WC), Interaction between MD and WC (AI), Variance of disequilibrium (VD) and Covariance of interaction (CI).

A minimum spanning network among haplotypes was constructed based on the number of different alleles between haplotypes. This assessment was developed using the ARLEQUIN 3.5 software package available at http://cmpg.unibe.ch/software/arlequin3/ (ExcoFFIER et al., 2005). The network was drawn using the HAPSTAR0.5 software available at http://www.fo.am/hapstar.

A hierarchical analysis of variance was used to partition the total variance into covariance components among individuals within subpopulation variation, variation among subpopulation within population and variation among populations by an Analysis of Molecular Variance (AMOVA) (EXCOFFIER et al., 1992). The departure of this analysis is a genetic distance matrix between haplotypes based on the number of different alleles. The significance of covariance components was tested using 999 permutations arbitrarily fixing the $P$ values at 0.05 . The fixation index $\left(\mathrm{F}_{\mathrm{ST}}\right)$ was calculated for pairwise subpopulations. These analyses were performed using GENALEX, a user-friendly cross-platform

Table 4. - Haplotypes shared between studied subpopulations of A. colubrina var cebil.

\begin{tabular}{lcccc}
\hline & Candelaria A & Candelaria B & Santa Ana A & Santa Ana B \\
\hline Candclaria A & - & & \\
Candelaria B & 2 & - & - \\
Santa $\Lambda$ na $\Lambda$ & 1 & 1 & 0 \\
Santa Ana B & $\mathbf{2}$ & 1 & - \\
\hline
\end{tabular}




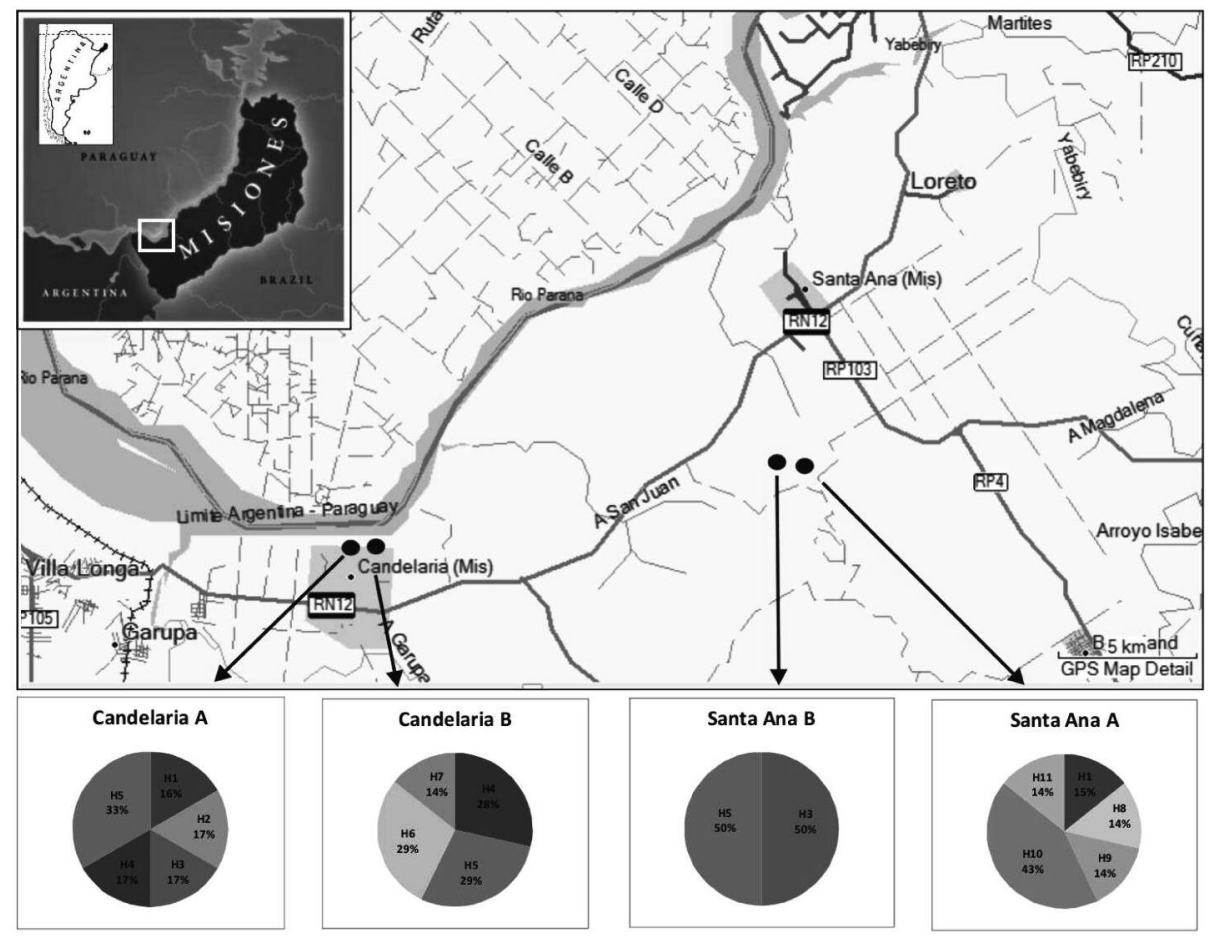

Figure 2. - Distribution of the eleven haplotypes in the sampled subpopulations of A. colubrina var cebil.

package available at http://www.anu.edu.au/BoZo/ GenAlEx/ (PEAKALL and SMouse, 2006)

An alternative differentiation measure (D), which is independent of heterozygosity, has been proposed by JOST in those cases where the $\mathrm{F}_{\mathrm{ST}}$ index could be biased by high allelic diversity values. This measure quantifies diversity at a gene locus as the inverse of gene identity $(1 / \mathrm{J})$, equivalent to the effective number of alleles (RYMAN and LEIMAR, 2009). Values were calculated using SMOGD vsn. 1.2 .5 available at http://www.ngcrawford. com/django/jost/ (CRAWFORD, 2010).

\section{Results}

cpSSR in A. colubrina var cebil

The four microsatellites obtained belong to two different microsatellite types: two perfect mononucleotide $\left[(\mathrm{T})_{8}\right.$ and $\left.(\mathrm{T})_{10}\right]$ and two compound imperfect repeats $\left[(\mathrm{T})_{7} \mathrm{C}(\mathrm{A})_{3} \mathrm{~T}(\mathrm{~A})_{10} /(\mathrm{A})_{10}\right.$ and $\left.(\mathrm{T})_{6} /(\mathrm{A})_{7} /(\mathrm{A})_{8}\right] \quad($ Table 1$)$. Sequences have been renamed and deposited in the GenBank public database with the accession numbers indicated in Table 1.

\section{cpSSRs alleles and chloroplast haplotypes}

Four cpSSR loci were analyzed and two of them (AcNtcp8 and AcNtcp9) showed polymorphic products in the twenty four accessions examined. Loci AcNtcp8 and AcNtcp 9 contained six and five alleles respectively with locus AcNtcp8 also exhibiting null alleles (Table 2). Allele 361 showed the highest frequency for locus AcNtcp 8 whereas allele 452 showed the highest frequency for locus AcNtcp9 (Table 2). Both alleles are present in Candelaria A, Candelaria B and Santa Ana B while
Santa Ana A had three unique alleles. This subpopulation also showed null alleles (Table 2). Eleven haplotypes were found as a result of different combinations of alleles from the two polymorphic loci (Table 3) with haplotype 5 displaying the highest frequency $(\mathrm{H} 5=0.2500)$ (Table 3). After subpopulation pairwise analysis Candelaria A and Candelaria B shared two haplotypes while Santa Ana A and Santa Ana B shared none (Table 4).

The distribution of the eleven haplotypes across the region analyzed showed a complex pattern. Haplotypes H1, H3 and H5 were scattered among three of the four populations examined (Figure 2). One out of eleven haplotypes was unique to Candelaria A and Candelaria B (H2 and $\mathrm{H} 7$ respectively), four were unique to Santa Ana A (H8, H9, H10 and H11) whereas Santa Ana B did not show any unique haplotypes. One common haplotype (H5) was shared by three of the four subpopulations analyzed (Figure 2).

\section{Genetic diversity}

The genetic diversity analysis yielded a high value $(G D=0.73)$. Brown's analysis for multilocus associations among and within subpopulations indicated that the single locus effect results in a high mean gene diversity $(\mathrm{MH}=0.446)$ and a low variance in diversity $(\mathrm{VH}=0.053)$. On the other hand, the two-locus component results in Wahlund's effect (WC $=0.077$ ) were lower than the interaction of $\mathrm{WC}$ and $\mathrm{MD}(\mathrm{AI}=0.013)$ (Table 5).

The minimum spanning network of haplotypes is shown in Figure 3. Some haplotypes were group-specific as is the case with $\mathrm{H} 1, \mathrm{H} 8, \mathrm{H} 9, \mathrm{H} 10$ and $\mathrm{H} 11$ present in Santa Ana A and H4, H5, H6 and H7 present in Candelaria B. It is worth noting that haplotypes H4 and H5 
Table 5. - Brown's analysis for multilocus associations among and within subpopulations.

\begin{tabular}{llc}
\hline Components of variance in the $\mathbf{N}^{\circ}$ of different haplotypes & \\
\hline Component & & $\begin{array}{c}\text { Variation } \\
\%\end{array}$ \\
\hline \multirow{2}{*}{ Simple locus effect } & Mean gene diversity (MH) & 0.446 \\
& Variance of diversity (VH) & 0.053 \\
& Wahlund's effect (WH) & -0.101 \\
\hline \multirow{3}{*}{ Two-loci effect } & Mean disequilibrium (MD) & 0.023 \\
& Wahlund's effect (WC) & 0.077 \\
& Interaction between MD and WC (AI) & 0.013 \\
& Variance of disecuilibrium (VD) & 0.038 \\
Total variance & Covariance of interaction (CI) & $-\mathbf{0 . 0 1 5}$ \\
Average variance & (MH+VH+WH+MD+WC+AI) & 0.512 \\
\hline
\end{tabular}

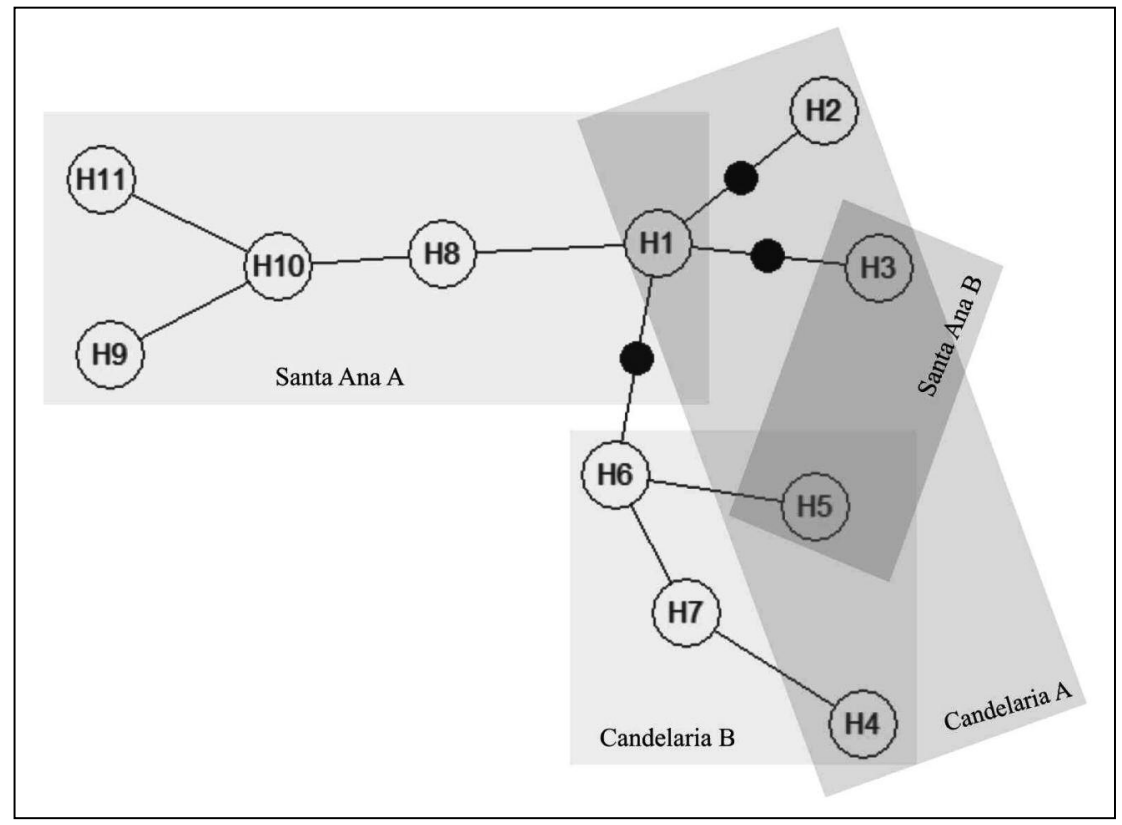

Figure 3. - Minimum Spanning Network for the chloroplast DNA haplotypes among subpopulations of A. colubrina var cebil. Haplotypes are represented with the same symbols as in Figure 2 and their origin is included.

Table 6. - Analysis of Molecular Variance (AMOVA) from a genetic distance matrix between haplotypes based on the number of different alleles.

\begin{tabular}{ccccc}
\hline Source of variation & d.f. & $\begin{array}{c}\text { Sum of } \\
\text { squares }\end{array}$ & $\begin{array}{c}\text { Variance } \\
\text { components }\end{array}$ & $\begin{array}{c}\text { Percentage of } \\
\text { variation }\end{array}$ \\
\hline $\begin{array}{c}\text { Among populations } \\
\text { Among subpopulations } \\
\text { within populations }\end{array}$ & 1 & 105331.576 & $105331.576 \mathrm{Va}$ & 17 \\
$\begin{array}{c}\text { Within subpopulations } \\
\text { Total }\end{array}$ & 20 & 214674.024 & $10733.701 \mathrm{Vc}$ & 48 \\
\hline & 23 & 430822.583 & 22383.852 & 100 \\
\hline
\end{tabular}


Table 7. - Fixation index for different hierarchical levels and statistical significance.

\begin{tabular}{lcc}
\hline \multicolumn{2}{c}{ Fixation index } & Significance values \\
\hline $\mathbf{F}_{\mathbf{R T}}$ & 0.175 & 0.079 \\
$\mathbf{F}_{\mathbf{P R}}$ & $0.419^{*}$ & 0.012 \\
$\mathbf{F}_{\mathrm{ST}}$ & $0.520^{*}$ & 0.005 \\
\hline
\end{tabular}

* Statistically significant (999 permutations).

were also present in other subpopulations. Santa Ana B only showed two haplotypes (H3 and H5) which were also present in other groups. Haplotype $\mathrm{H} 1$ was located at the center of the network.

AMOVA indicated that the total variance was distributed mainly within subpopulations where the highest percentage of variation (48\%) was found (Table 6). The fixation index $\left(\mathrm{F}_{\mathrm{ST}}\right)$ was statistically significant with a high value $\left(\mathrm{F}_{\mathrm{ST}}=0.520 ; \mathrm{p}<0.05\right)$ (Table 7$)$. The $\mathrm{F}_{\mathrm{ST}}$ comparison between Candelaria A and Santa Ana B subpopulations did not show significant genetic differentiation and a similar situation was observed between Santa Ana A and Santa Ana B (Table 8).

The Jost differentiation global index $\left(\mathrm{D}_{\text {est }}\right)$ was 0.049 . In most cases, $\mathrm{D}_{\text {est }}$ comparison values between subpopulation pairs were zero except in those cases where Santa Ana A was involved (Table 9).

\section{Discussion}

To our knowledge, this study represents the first analysis of cytoplasmic DNA diversity within Argentina's northeastern native species.
The use of universal primers has notorious benefits in terms of development costs and time requirements as a strategy for accessing cpSSR variation in novel species (EBERT and PEAKALl, 2009). All four cpSSRs tested were able to yield PCR amplification products successfully in A. colubrina.

Ntcp primers were developed from mononucleotide simple-sequence repeats in the $N$. tabacum chloroplast genome. These primers were tested in other members of the Solanaceae where they revealed high levels of interspecific chloroplast DNA variation (BRYAN et al., 1999b). However, Ntcp9 was excluded from the genetic diversity analysis in Vitellaria paradoxa due to problems with allele detection in gel-based assays. On the other hand Ntcp8 was included in this study and showed four alleles (FonTAINE et al., 2004). Only five out of thirty six Ntcp primers (namely Ntcp8, Ntcp9, Ntcp37, Ntcp39, and Ntcp40) generated PCR amplification products and polymorphism was observed at each locus except for Ntcp40 in phylogenetic studies in yams (CHAÏR et al., 2005). These studies indicated that Ntcp primers could not be considered strictly universal but species-specific cpSSR primers. Null alleles within Ntcp8 were detected in A. colubrina var cebil, probably due to changes in the nucleotide sequence of microsatellite's flanking regions which prevent primer annealing during the amplification process. Such variations occur at a non-negligible rate (CHAPUIS and ESTOUP, 2007).

The four novel $A$. colubrina var cebil microsatellite sequences were rich in $\mathrm{A} / \mathrm{T}$, in agreement with the numerous chloroplast sequences deposited in GenBank (Powell et al., 1995; EBerT and PEAKAll, 2009).

Although cpDNA non-coding regions show a relatively low base-substitution rate, two loci were polymorphic in PCR fragment size and showed several alleles in A. colu-

Table 8. $-\mathrm{F}_{\mathrm{ST}}$ pairwise comparisons of studied subpopulations. $\mathrm{F}_{\mathrm{ST}}$ values below diagonal. Probability values are based on 999 permutations above diagonal.

\begin{tabular}{ccccc}
\hline & Candelaria A & Candelaria B & Santa Ana A & Santa Ana B \\
\hline Candelaria A & 0.000 & 0.007 & 0.025 & 0.418 \\
Candelaria B & $0.450^{*}$ & 0.000 & 0.001 & 0.038 \\
Santa Ana A & $0.488^{*}$ & $0.520^{*}$ & 0.000 & 0.075 \\
Santa Ana B & 0.000 & $0.506^{*}$ & $0.417^{*}$ & 0.000 \\
\hline
\end{tabular}

*Statistically significant.

Table 9. $-\mathrm{D}_{\text {est }}$ pairwise comparisons of subpopulations under study.

\begin{tabular}{lcccc}
\hline & Candelaria A & Candelaria B & Santa Ana A & Santa Ana B \\
\hline Candelaria A & - & 0.000 & 0.118 & 0.000 \\
Candelaria B & - & 0.225 & 0.000 \\
Santa Ana A & & - & 0.140 \\
Santa Ana B & & & - \\
\hline
\end{tabular}


brina var cebil. The maximum size difference among these alleles was $11 \mathrm{bp}$ for locus AcNtcp8 and 16 for locus AcNtcp9. Single nucleotide polymorphisms and insertion-deletion polymorphisms (indels) are common in chloroplast non- coding regions (CESARE et al., 2010). This would explain why other Ntcp primers such as Ntcp40 and Ntcp49 showed irregular gaps of several base pairs in Carya illinoinensis (GRAUKE et al., 2010). Indels would then be responsible for the observed differences in size among alleles in our study.

High haplotype diversity was detected as a result of the large number of alleles observed in both loci, a fact that was also reflected in the high mean gene diversity value $(G D=0.73)$. We found 11 haplotypes in 24 trees from two populations. This result contrasts with some data published in the literature for other species. In this way, CAVERs et al. (2003) found five haplotypes in 29 populations of Cedrela odorata and ANDRIANOELINA et al. (2006) found 13 haplotypes in 100 individuals from 10 locations of Dalbergia monticola (Fabaceae).

The most frequent haplotype (H5) was defined by combination of the most frequent alleles (361 and 452) and was scattered among three of the four analyzed populations (Candelaria A, Candelaria B and Santa Ana B). Santa Ana A showed the highest number of unique haplotypes, suggesting that it is the most differentiated subpopulation.

The structure of multilocus association among and within populations was partitioned into its components. The single locus component analysis showed high mean gene diversity $(\mathrm{MH}=0.446)$ and low variance in diversity $(\mathrm{VH}=0.053)$. A substantial and positive interaction between $\mathrm{MD}$ and $\mathrm{WC}$ values (AI) when using two-loci component analysis indicates that the correlation of alleles between populations is coincident with the pattern observed within populations (BROWN and FELDMAN, 1981). In our study, this interaction showed that the correlation of alleles between populations did not repeat the pattern within populations reflecting that population substructure is present. In addition, this population substructure might be invoked when Wahlund's effect (WC) is high but interaction between $\mathrm{MD}$ and $\mathrm{WC}$ (AI) is low (BROWN and FELDMAN, 1981). Our present results indicate that the fixation index value $\left(\mathrm{F}_{\mathrm{ST}}=0.52\right)$ strengthened this result even when the $\mathrm{F}_{\mathrm{ST}}$ was calculated using a haplotypic distance matrix. The analysis of molecular variance (AMOVA) was developed to quantify the contribution of different population structure levels to genetic variation. The total variance was distributed mainly within subpopulations $(48 \%)$. However, the level between populations reached $17 \%$.

While AMOVA is a powerful and robust approach, randomization is limited by sample size (FITZPATRICK, 2009). We should also keep in mind that when using hierarchical randomization tests the number of groups at each level affects the statistical power at that specific level (FITZPATRICK, 2009). It has been suggested that evaluating all pairwise comparisons might be more informative and forthright when analyzing small numbers of populations. Due to this, some authors consider that more information might be obtained by performing separate analysis of unlinked loci and combining inferences across loci (FiTZPATRICK, 2009). We were unable to perform this analysis of unlinked loci due to the lack of cpDNA recombination. All $\mathrm{F}_{\mathrm{ST}}$ pairwise comparisons (Table 8) showed analogous results and emphasized subpopulation Santa Ana A as the most distant subset.

The Jost's D index was estimated as a consequence of the high diversity level detected. These global statistics did not show any genetic structure $\left(\mathrm{D}_{\text {est }}=0.049\right)$. On the other hand, $\mathrm{D}_{\text {est }}$ comparison between subpopulations showed some degree of differentiation. All comparisons against Santa Ana A suggested the existence of genetic structure (Table 9), which could be derived from the presence of unique haplotypes.

Statistical differences $\left(\mathrm{F}_{\mathrm{ST}}\right.$ vs. $\left.\mathrm{D}_{\text {est }}\right)$ may result from variations in the theoretical development of these mathematical tools. Currently, $\mathrm{D}_{\text {est }}$ is considered a real differentiation measure since its index is quantified in terms of the effective number of alleles and thereby is independent of heterozygosity (JOST, 2008; RYMAN and LEIMAR, 2009). Thus, $D_{\text {est }}$ quantifies diversity at a gene locus as the inverse of gene identity $(1 / \mathrm{J})$, equivalent to the effective number of alleles (RYMAN and LEIMAR, 2009) whereas, in our study, $\mathrm{F}_{\mathrm{ST}}$ was estimated from the distance between haplotypes. In this way, $\mathrm{F}_{\mathrm{ST}}$ has been more informative than Dest when performing a cpDNA diversity analysis in A. colubrina var cebil.

The minimum spanning network reflected the differentiation among subpopulations. Related haplotypes identified clear groups which can be assigned to at least three subpopulations. The position of haplotype $\mathrm{H} 1$ in the network indicated that it is the ancestral haplotype (Figure 3).

It may seem surprising to find that fragmented populations display large levels of cpDNA diversity when drift and reduced gene flow should indeed reduce diversity as isolation increases. The Upper Parana Atlantic Forest was originally covered by a continuous semideciduous subtropical forest with a high diversity of plant species. The greatest threat to diversity in this region is the extreme degree of fragmentation and forest degradation. This fragmentation comes as a result of the expansion of cultivated areas (DI BITETTI et al., 2003). Starting in the '60s and '70s, the Misiones forest has been deeply impacted as a consequence of the replacement of native species by exotic ones introduced for the purpose of forest exploitation (MAC DONAGH and RIVERO, 2005). The high level of diversity detected in the adult trees of $A$. colubrina var cebil from the populations studied could be due to recent human impact reducing the population size. In this scenario, genetic drift needs long periods of time to fix or lose haplotypes. Therefore, the reduction in population size causes a subsequent reduction in the number of trees, i.e. surviving trees may be showing the historical diversity of the A.colubrina var cebil populations analyzed.

Considering that only $7.4 \%$ of the Upper Parana Atlantic Forest original cover still remains (JARAMILLO et al., 2005) urgent conservation strategies are required and the first step to design them is to know their genetic diversity. 


\section{Acknowledgements}

We would like to thanks M. Z. GALVÁN for helpful comments. We are grateful for the valuable comments made by two anonymous reviewers which contributed to improve the manuscript. M. E. BARRANDEGUY is supported by a Doctoral Fellowship provided by Consejo Nacional de Investigaciones Científicas y Técnicas (CONICET) from Argentina.

\section{Bibliography}

Abraham De Noir, F., S. Bravo and R. Abdala (2002): Mecanismos de dispersión de algunas especies leñosas nativas del chaco occidental y serrano. Quebracho Revista de Ciencias Forestales 9: 140-150.

AndRianoelina, O., H. Rakotondraoelina, L. RAmamonJisoa, J. Maley, P. Danthu and J. M. Bouvet (2006): Genetic diversity of dalbergia monticola (fabaceae) an endangered tree species in the fragmented oriental forest of Madagascar. Biodiversity and Conservation 15: 1109-1128.

Brown, A. H. D. and M. W. Feldman (1981): Population structure of multilocus associations. Proc Natl Acad Sci 78(9): 5913-5916.

Bryan, G., W. De Jong, J. Provan, D. Milbourne, J. MCNicoll, J. DAVISON, G. RAMSAY and R. WAUGH (1999a): Potato genomics: a strategy for the molecular genetic characterization of Solanum germplasm. Annual report 1998/1999. Scott Crop Res Inst Genet Breed 101-104.

Bryan, G., J. McNicoll, G. Ramsay, R. C. Meyer and W. S. DE JoNG (1999b): Polymorphic simple sequence repeats markers in chloroplast genomes of Solanaceous plants. Theor Appl Genet 99: 859-867.

CATO, S. A. and T. E. Richardson (1996): Inter- and intraspecific polymorphism at chloroplast SSR loci and the inheritance of plastids in Pinus radiata D. Don. Theor Appl Genet 93: 587-592.

CAVErs, S., C. NAVARRo and A. J. Lowe (2003): Chloroplast DNA phylogeography reveals colonization history of a Neotropical tree, Cedrela odorata L., in Mesoamerica. Mol. Ecol. 12: 1451-1460.

Cavers, S., C. Navarro and A. J. Lowe (2004): Targeting genetic resource conservation in widespread species: a case study of Cedrela odorata L. Forest Ecology and Management 197: 285-294.

Cesare, M., T. R. Hodkinson and S. BARTH (2010): Chloroplast DNA markers (cpSSRs, SNPs) for Miscanthus, Saccharum and related grasses (Panicoideae, Poaceae). Mol Breeding 26: 539-544.

ChaÏr, H., X. Perrier, C. Agbangla, J. L. Marchand, O. DAINOU and J. L. NOYER (2005): Use of cpSSRs for the characterization of yam phylogeny in benin. Genome 48: 674-684.

Chapuis, M. and A. Estoup (2007): Microsatellite null alleles and estimation of population differentiation. Mol Biol Evol 24(3): 621-631.

Cheng, Y., W. Guo and X. Deng (2003): CpSSR: a new tool to analyze chloroplast genome of citrus somatic hybrids. Acta Botanica Sinica 45(8): 906-909.

Cialdella, A. M. (2000): Flora Fanerogámica Argentina. Proflora. Fascículo 67: Fabaceae Subfamilia Mimosoideae: $1-10$.

Crawford, N. G. (2010): SMOGD: Software for the measurement of genetic diversity. Mol Ecol 10(3): 556-557.
Di Bitetti, M. S., G. Placci and L. A. Dietz (2003): Una visión de biodiversidad para la ecorregión del Bosque Atlántico del Alto Paraná: diseño de un paisaje para la conservación de la biodiversidad y prioridades para las acciones de conservación. Washington, D.C., World Wildlife Fund.

Doulaty Baneh, H., S. A. Mohammadi, M. Labra, A. Nazemieh, F. De MatTia and M. Mardi (2007): Chloroplast microsatellites markers to assess genetic diversity in wild and cultivated grapevines of Iran. Pak J Biol Sci. 10(11): 1855-1859.

Ebert, D. and R. Peakall (2009): Chloroplast simple sequence repeats (cpSSRs): technical resources and recommendations for expanding cpSSR discovery and applications to a wide array of plant species. Mol Ecol 9(3): 673-690.

Excoffier, L., P. E. Smouse and J. M. QuATtro (1992): Analysis of molecular variance inferred from metric distances among DNA haplotypes: application to human mitochondrial DNA restriction data. Genetics 131: $479-491$.

Excoffier, L., G. LAVAL and S. SchneIDER (2005): Arlequin ver. 3.0: An integrated software package for population genetics data analysis. Evol Bioinform Online 1: 47-50.

FitZPATRICK, B. M. (2009): Power and simple size for nested analysis of molecular variance. Mol Ecol 18: 3961-3966.

Fontaine, C., P. N. Lovett, H. Sanou, J. Maley and J. M. Bouvet (2004): Genetic diversity of the shea tree (Vitellaria paradoxa C.F. Gaertn), detected by RAPD and chloroplast microsatellite markers. Heredity 93: 639-648.

García, M. V., P. A. Balatti and M. J. Arturi (2007): Genetic variability in natural populations of Paspalum dilatatum Poir. analized by means of morphological traits and molecular markers. Genet Resour Crop Evol 54(5): 935-946.

Gómez, A., E. Aguiriano, R. Alía and M. A. Bueno (2002): Análisis de los recursos genéticos de Pinus pinea L. en España mediante microsatélites de cloroplasto. Invest Agr: Sist Recur For 11(1): 145-154.

Grauke, L. J., M. A. MendozA-Herrera and M. L. BinzeL (2010): Plastid Microsatellite Markers in Carya. Acta Hort 859: 237-246.

Grivet, D., B. Heinze, G. G. Vendramin and R. J. Petit (2001): Genome walking with consensus primers: application to the large single copy region of chloroplast DNA. Molec Ecol Not 1: 345-349.

HALL, T. A. (1999): BioEdit: a user-friendly biological sequence alignment editor and analysis program for windows 95/98/nt. Nucl. Acids Symp Ser 41: 95-98.

HARRIS, S. A. and R. INGRAM (1991): Chloroplast DNA and biosystematics: the effects of intraspecific diversity and plastid transmission. Taxon 40: 393-412.

Jaramillo, M., E. Carabelli, S. Ferrari, V. Guerrero Borges, L. AREJola and D. Rode (2005): Planificación comunitaria participativa: trabajando por el uso y la conservación de la selva paranaense, pp 217-221. In: La situación Ambiental Argentina, edited by A. BROwN, U. Martinez Ortiz, M. Acerbi and J. Corcuera, Fundación Vida Silvestre Argentina, Buenos Aires.

JosT, L. (2008): $\mathrm{G}_{\mathrm{ST}}$ and its relatives do not measure differentiation. Mol Ecol 17(18): 4015-4026.

Justiniano, M. J. and T. S. Fredericksen (1998): Ecología y silvicultura de especies menos conocidas: curupaú. Anadenanthera colubrina (vell. conc.) benth. Mimosoideae. Proyecto de manejo forestal sostenible bolfor. 
Kaundun, S. S. and S. Matsumoto (2002): Heterologous nuclear and chloroplast microsatellite amplification and variation in tea, Camellia sinensis. Genome 45: 1041-1048.

LAROCHE, J. and J. D. DURAND (2004): Genetic structure of fragmented populations of a threatened endemic percid of the Rhone river: Zingel asper. Heredity 92(4): 329-334.

Mac Donagh, P. and L. Rivero (2005): ¿Es posible el uso sustentable de la selva Misionera?, pp. 210-217. In: La situación Ambiental Argentina, edited by A. BRown, U. Martinez Ortiz, M. ACERBI and J. CorcuerA, Fundación Vida Silvestre Argentina, Buenos Aires.

Marchelli, P. and L. Gallo (2006): Multiple ce-age refugia in a southern beech of South America as evidenced by chloroplast DNA markers. Cons Genet 7: 591-603.

Marchelli, P., C. Baier, C. Mengel, B. Ziegenhagen and L. A. Gallo (2010): Biogeographic history of the threatened species Araucaria araucana (Molina) K. Koch and implications for conservation: A case study with organelle DNA markers. Conserv Genet 11: 951-963.

NEI, M. (1987): Molecular evolutionary genetics. Columbia University Press, New York. 512p.

Pastorino, M. J., P. Marchelli, M. Milleron, C. Solian and L. A. GALlo (2009): The effefct of different glaciation patterns over the current genetic structure of the southern beech Nothofagus antartica. Genetica 136(1): 79-88.

Peakall, R., S. Gilmore, W. Keys, M. Morgante and A. RAFALSKI (1998): Cross-Species Amplification of Soybean (Glycine max) Simple Sequence Repeats (SSRs) Within the Genus and Other Legume Genera: Implications for the Transferability of SSRs in Plants. Mol Biol Evol 15(10): 1275-1287.
Peakall, R. and P. E. Smouse (2006): Genalex 6: genetic analysis in Excel. Population genetic software for teaching and research. Mol Ecol Not 6(1): 288-295.

Powell, W., M. Morgante, R. McDevitt, G. G Vendramin and J. A. RAFALSKI (1995): Polymorphic simple sequence repeats regions in chloroplast genomes: Applications to the population genetics of pines. Proc Natl Acad Sci USA 92(17): 7759-7763.

Provan, J., W. Powell and P. M. Hollingsworth (2001): Chloroplast microsatellites: new tools for studies in plant ecology and evolution. Trends Ecol Evol 16(3): 142-147.

Ryman, $\mathrm{N}$ and O. LeIMAR (2009): $\mathrm{G}_{\mathrm{ST}}$ is still a useful measure of genetic differentiation - a comment on Jost's D. Mol Ecol 18: 2084-2087.

SAmbrook, J., E. F. Fritsch and T. Maniatis (1989): Molecular Cloning: A Laboratory Manual. Cold Spring Harbor Laboratory Press.

SChUSTER, I. and C. D. CRUZ (2004): Estatística genómica aplicada a populações derivadas de cruzamentos controlados. Viçosa MG: Editora UFV 568p.

Steiner, J. J., C. J. Pocklemba, R. G. FJellstrom and L. F. Elliot (1995): A rapid one tube genomic DNA extraction process for PCR and RAPD analyses. Nucleic Acid Res 23(13): 2569-2570.

WEISING, K. and R. C. GARDNeR (1999): A set of conserved PCR primers for the analysis of simple sequence repeat polymorphisms in chloroplast genomes of dicotyledonous angiosperms. Genome 42(1): 9-19.

YEH, F. C. and T. J. B. BoYLE (1997): Population genetic analysis of co-dominant and dominant markers and quantitative traits. Belg J Bot 129: 157.

ZANe, L., L. BARgelloni and T. PATARNello (2002): Strategies for microsatellite isolation: a review. Mol Ecol 11: $1-16$.

\title{
Heritability of Yield and Secondary Traits in two populations of Para Rubber Tree (Hevea brasiliensis)
}

\author{
By C. NARAYANAN*) and KaVitha K. MYdin
}

(Received $4^{\text {th }}$ May 2010)

\begin{abstract}
Heritability and interactions of yield and growth traits were assessed in Hevea brasiliensis using full-sib progenies and clonal populations. Using parent-offspring regression, annual mean rubber yield (ARY) and summer yield (SY) showed moderate to high heritability (ARY, $h^{2}=34-56 \%$; SY, $h^{2}=36-52 \%$ ). Among the yield components, girth exhibited low to moderate heritability $\left(h^{2}=17-36 \%\right)$ while branching height showed low heri-

\footnotetext{
*) Corresponding author: C. NARAYANAN. Crop Improvement Group, Botany Division, Rubber Research Institute of India, India. Ph: +91-481-2353311, Fax: +91-481-2353327. E-Mail cnarayanan@rubberboard.org.in
}

tability $\left(h^{2}=18 \%\right)$. Using forty clonal genotypes, annual mean rubber yield $\left(H^{2}=48 \%\right)$, rubber yield during peak period $\left(H^{2}=47 \%\right)$ and rubber yield during stress (or summer yield) $\left(H^{2}=44 \%\right)$ showed high estimates of heritability. Among the other yield components, except volume of latex during stress period $\left(H^{2}=40 \%\right)$, remaining yield components showed moderate estimates for heritability $\left(H^{2}=29-37 \%\right)$. Dry rubber content (DRC) based on annual mean showed very high heritability $\left(H^{2}=68 \%\right)$, followed by DRC during stress $\left(H^{2}=51 \%\right)$ and peak $\left(H^{2}=50 \%\right)$ periods. Latex flow rate based on annual mean and peak period data showed high heritability $\left(H^{2}=51 \%\right)$ followed by latex flow rate during stress period $\left(H^{2}=42 \%\right)$. Plugging indices of annual and 